\title{
Облітеруючі захворювання судин нижніх кінцівок у дітей: нові підходи у лікуванні з використанням клітинних технологій
}

\author{
M. F. DRIUK, V. I. KIRIMOV, D. B. DOMBROVSKYI \\ National Institute of Surgery and Transplantology by O. O. Shalimov of NAMS of Ukraine
}

\section{OBLITERANS DISEASES OF VESSELS OF LOWER LIMBS IN CHILDREN: NEW APPROACHES IN TREATMENT USING THE CELLTECHNOLOGIES}

\begin{abstract}
Захворювання артерій кінцівок тривалий час було виключно прерогативою людей старшого віку, проте сьогодні з'являсться все більше повідомлень про облітеруючі захворювання артерій кінцівок у дітей. Цей контингент хворих досить складний, оскільки діагностика і тактика лікування викликають труднощі і вимагають прийняття нестандартних рішень. Представлено випадки таких клінічних ситуацій, у яких були застосовані непрямі методи реваскуляризації кінцівок шляхом трансплантації власних мультипотентних стромальних клітин кісткового мозку та жирової тканини.

A disease of arteries of extremities long time was exceptionally the prerogative of people in age, however today more ofter appears reports about the obliterans diseases of arteries of extremities in children. This contingent of patients is difficult enough, as diagnostics and tactic of treatment and requires acceptance of non-standard decisions. There are presented the cases of such clinical situations in which indirect methods of revascularization of extremities were applied, by transplantation of own multipotents stromal cells of marrow and fatty tissue.
\end{abstract}

Постановка проблеми і аналіз останніх досліджень та публікацій. Облітеруючі захворювання судин нижніх кінцівок у дітей можна віднести до казуїстичних, однак на сьогодні ситуація змінилась. Ураження дистального артеріального русла нижніх кінцівок спостерігають все частіше у пацієнтів молодого та дитячого віку. Питання тактики лікування, методи терапевтичного та хірургічного лікування у таких хворих не вирішені. Важливо зауважити, що організм ще росте та розвивається, а ураження артеріального сегмента локалізується зазвичай лише гомілкою та ступнею. Застосування препаратів нового покоління, зокрема препаратів простагландину E1 (Вазопростан), простацикліну (Іломедин), які досить добре зарекомендували себе у лікуванні хворих старшого віку з таким ураженням, не рекомендоване виробниками цих ліків у пацієнтів дитячого віку. Навпаки, застосування препарату сулодексиду (Вессел Дує Ф) з доведеною ангіопротекторною дією вже має досвід у комплексному лікуванні дітей та підлітків, зокрема при цукровому діабеті. Традиційна судинна інфузійна терапія, згідно з нашими спостереженнями, не завжди дозволяє отримати позитивний ефект лікування. Тому актуальними і важливими є пошуки нових не- стандартних методів реваскуляризації кінцівки, зокрема на основі стимуляції неоангіогенезу в ішемізованих тканинах. Одним із напрямків досліджень $€$ використання клітинних технологій, які включають методи стимуляції хемотаксису ангіогенних клітин у вогнище ураження або введення клітин, що стимулюють процеси ангіогенезу як внаслідок збільшення виділення ангіогенних цитокінів, так і шляхом безпосередньої реконструкції судинного русла за допомогою трансплантованих клітин. 3 цією метою використовують стромальні стовбурові клітини кісткового мозку $[1,2]$. Проте використання мезенхімальних стовбурових клітин кісткового мозку у клініці проблематичне, оскільки процедура його отримання складна (потребується використання дорогого лабораторно-інструментального забезпечення на основі магнітно-активованого клітинного сортування) i, до того ж, вдається зібрати малу кількість клітин. Одним із найбільш простих на даний момент методів $є$ використання аутоаспірату кісткового мозку хворого, що містить популяцію мезенхімальних стовбурових клітин (це плюрипотентні клітини, резиденти строми кісткового мозку), здатних проліферувати та диференціюватись в кількох напрямках: нейрональному, ангіоген- 
ному, хондрогенному, адипоцитарному, кардіоміоцитарному, міоцитарному [3, 4]. Одним із напрямків їх диференціації, а саме при трансплантації їх у вогнище ішемії (відомо, що ішемія в тканинах є стимулюючим фактором), є ангіогенний напрямок, за рахунок якого відбувається стимуляція ангіогенезу (M. G. Cavallo, P. Rozzilli, 1994, P. A. Taguchi, T. Soma, 2003). У відділі мікросудинної та пластичної хірургії HIXT методику забору та аутотрансплантацію аспірату кісткового мозку (АтАКМ) у тканини-м'язи нижніх кінцівок (НК) як монометод виконано у 120 хворих (223 НК). Також одним із перспективних джерел стовбурових клітин в організмі є жирова тканина, однак характер впливу стовбурових клітин цього походження на ішемічні прояви сьогодні мало вивчено. Аналіз експресії людськими стромальними клітинами жирової тканини (СКЖТ) антигенів на клітинній мембрані, проведений із специфічними антитілами на поточному цитофлуориметрі, показав, що більшість маркерів, присутніх на поверхні СКЖТ, схожі з маркерами, виявленими на поверхні мезенхімальних клітин кісткового мозку, що може свідчити про їх єдине походження i, можливо, схожу пластичність, тобто здатність диференціюватися у різні типи клітин. Перевагами СКЖТ для використання в терапевтичних цілях $є$ відносна легкість їх виділення з тканини і можливість отримання в достатньо великій кількості. Зразки жирової тканини, отримані в результаті косметичної ліпосакції, або в ході хірургічного видалення жирового відкладення, піддаються ферментативній обробці колагеназою у поєднанні з еластазою, внаслідок чого виходить суспензія окремих клітин, з якої при подальшому центрифугуванні виділяється осадова фракція клітин стромально-васкулярного фенотипу. На сьогодні розроблено технологію виділення мультипотентних стромальних клітин жирової тканини (МСК ЖТ) (5), яка включає в себе на першому етапі отримання ЖТ шляхом ліпоаспірації. 3 жирового аспірату виділяється стромально-васкулярна фракція (СВФ). Нами розроблено технологію трансплантації аутологічних МСК ЖТ хворим на хронічну ішемію кінцівок. Частину СВФ вводили внутрішньом'язово в кінцівку (сегмент “гомілка-стопа"), інша частина клітин залишається на питомому середовищі для проведення експансії. Через 2-3 тижні проводиться введення культивованих стромальних клітин ЖТ в ішемізовану кінцівку. Ця методика застосована нами у 10 хворих.

Матеріали і методи. У відділі мікросудинної та пластичної хірургї̈ НIXТ НАМН України ім. О. О. Шалімова за останні 5 років перебували на спостереженні та приймали лікування 6 хворих, 3 них 1 дівчинка віком 11 років та 5 хлопчиків віком $9,12,13,13,14$ років. Всім хворим було встановлено діагноз: облітеруючий ендартеріїт судин нижніх кінцівок. У всіх хворих спостерігали ураження гомілкового сегмента. Хворі обстежені на антифосфоліпідний синдром, який може часто супроводжувати тяжку хронічну патологію (у тому числі онкологічну) - дані негативні. У 4 хлопчиків 9 та 13 років (з II та ІІб стадією захворювання (за FontaineПокровським) було проведено традиційне судинне консервативне лікування (2 з них прийняли курс препарату сулодексиду), курс фізіотерапевтичних процедур. Досягнуто позитивний ефект, а саме: повністю купірувано больовий синдром, нормалізувався сон, збільшилась безболісна дистанція ходи. Зважаючи на недостатню ефективність терапевтичного лікування у двох інших хворих, їм були застосовані хірургічні методи. Більш детально обговоримо 2 клінічних спостереження (хлопчик 14 років та дівчинка 11 років).

\section{Клінічне спостереження}

Хворий Р. віком 14 років госпіталізований у відділ мікросудинної та пластичної хірургії в червні 2008 зі скаргами на різкий біль в обох гомілках та пальцях стопи, порушення сну в зв' язку з появою нічного болю, що в останній час турбує майже кожну ніч та змушує хворого часто опускати кінцівки, лежачи на ліжку, приймати знеболювальні ліки. Скаржиться на переміжну кульгавість через 40-45 метрів. Хворіє майже рік, коли почав відмічати появу болю в гомілках при фізичних навантаженнях. Хворий (з його слів та слів матері) із 7 років курить цигарки, останні півроку більше 20 сигарет на день. Судинний хірург клініки за місцем помешкання призначив консервативне лікування, що не дало позитивного ефекту. Шість місяців тому перебував на обстеженні в інституті педіатрії. Прийняв курс препарату "Вазопростан" по 20 мкг 1 раз на день внутрішньовенно краплинно № 10, однак помітного позитивного ефекту не одержав: больовий синдром практично залишився. Два місяці тому відмічає появу потемніння шкіри I пальця лівої ступні та II пальця правої ступні. В останні 2 тижні на місцях останніх утворились некротичні трофічні виразки. При об' єктивному обстеженні шкіра на обох гомілках та ступнях блідого кольору, при пальпації прохолодна. Рухи в суглобах обох ніг, активні та пасивні, збережені, задовільні. Шкірна та суглобова чутливість на обох ногах збережена. Відмічаються осередки некрозу з гнійним виділенням I пальця лівої ступні, II пальця правої ступні, локальні поверхневі некрози дистальних фаланг I, III, IV пальців правої ступні, трофічна виразка V пальця. Пальпа- 
торно чітка пульсація на підколінній артерії з обох сторін. На задній великогомілковій артерії та тильній артерії пульсація не визначається. Хворому було виконано інструментальні обстеження. Дослідження сегментарного тиску на НК (момент госпіталізації). Права гомілка: задня гомілкова артерія (ЗГА) - 30 мм рт. ст.; передня гомілкова артерія (ПГА) - 40 мм рт. ст.; пульсація біля I пальця ступні - не визначається; кісточково-плечовий індекс (КПI) - 0,34. Ліва гомілка: ЗГА - 50 мм рт. ст.; ПГА - 40 мм рт. ст.; пульсація біля I пальця ступні - не визначається; КПІ - 0,43. Артеріальний тиск плеча - 125/80 мм рт. ст. Рентгеноконтрастна ангіографія: на правій НК спостерігається оклюзія гомілкових артерій на рівні середньої третини гомілки, через колатералі заповнюються фрагменти ЗГА, фрагменти тильної артерії ступні. На лівій НК спостерігається оклюзія ПГА на рівні верхньої третини гомілки, оклюзія ЗГА на рівні $5 \mathrm{~cm}$ вище кісточки. Хворому встановлено діагноз: облітеруючий ендартеріїт артерій нижніх кінцівок. Оклюзія гомілкового сегмента з обох сторін. Некроз I пальця лівої ступні, II пальця правої ступні, локальні поверхневі некрози м'яких тканин I, III, IV пальців правої ступні та на тильній поверхні у ділянці V пальця. Хронічна артеріальна недостатність IV ступеня (за Fontaine-Покровським). Хронічна критична ішемія нижніх кінцівок. Враховуючи клінічні прояви та перебіг захворювання, стадію, вік пацієнта, період загострення хвороби на момент госпіталізації, а також дані функціональних та рентгенангіографічних досліджень - реконструктивні операції та ендоваскулярні втручання на судинах не показані у зв'язку з відсутністю анатомічних передумов. Консервативна терапія з використанням препаратів простагландинів виявилась неефективною. Вирішено використати метод непрямої реваскуляризації, а саме АтАКМ хворого у тканини-м'язи гомілки та ступні НК (у “вогнище” ішемії). 3 метою радикальної санації гнійнонекротичних ран на обох ступнях першим етапом була виконана операція (23.06.2008 р.): екзартикуляція I пальця лівої ступні та II пальця правої ступні, пластика дефекту тканин трофічної виразки по тилу ступні штучним покриттям Suspur derm. Наступним етапом була виконана операція (9.07.2008 р.): АтАКМ у тканини-м' язи обох гомілок (по 70,0 мл) та в обидві стопи (по 20,0 мл) згідно 3 методикою, розробленою в клініці. Аспірат кісткового (АКМ) мозку отримано з крила клубової кістки за допомогою спеціального інструмента. У найближчий післяопераційний період (3-5 доба) у хворого відмічено поліпшення: значно зменшився біль, що корелювало із зменшенням кратності введення зне- болювальних препаратів, потеплішала шкіра кінцівки, став спокійнішим сон. На 12-ту добу відмічено спонтанне загоєння локальних поверхневих некрозів м'яких тканин I, III, IV пальців правої ступні. Рана по тилу правої ступні, котра була раніше санована та закрита штучним покриттям, зменшилась у розмірах і поступово виповнюється. Кукси I пальця лівої ступні та ІІ пальця правої ступні гояться первинним натягом. На 12-ту добу після операції АтАКМ було виконано дослідження сегментарного тиску на НК у динаміці. Права гомілка: ЗГА - 45 мм рт. ст.; ПГА - 50 мм рт. ст.; пульсація біля I пальця ступні - не визначається; КПІ 0,45. Ліва гомілка: ЗГА - 65 мм рт. ст.; ПГА 55 мм рт. ст.; пульсація біля I пальця ступні - не визначається; КПІ - 0,59. Артеріальний тиск плеча - 110/70 мм рт. ст. На 15-ту добу після операції АтАКМ за бажанням хворого та його родичів пацієнт був виписаний на амбулаторне лікування по місцю мешкання. На момент виписування з клініки загальний стан хворого задовільний, опорна функція обох НК збережена. Рани та трофічна виразка правої ступні загоїлись первинним натягом. Через 3,5 місяця після виписування пацієнт повторно звертається в клініку із скаргами на рану в ділянці кукси I пальця лівої ступні. 3 його слів, 12 днів тому вдома на фоні абсолютного благополуччя, виконуючи фізичні вправи, хворий жорстко травмував ліву ступню (ділянка кукси I пальця) ударом у твердий предмет. Відмічає безбольову дистанцію ходи більше кілометра. Рану лікував вдома, накладаючи різні мазі, останні 4 доби відмічає гнійне виділення з рани з різким болем. При об'єктивному обстеженні шкіра на обох ногах звичайного кольору, на лівій ступні більш ціанотична та дещо прохолодніша при пальпації, чутливість шкіри та активні рухи нижніх кінцівок збережені. Пульсація збережена на підколінних артеріях обох НК, пульсація артерій на ступнях не визначається. Дані дослідження сегментарного тиску на НК (30.10.2008 р.). Права гомілка: ЗГА - 30 мм рт. ст.; ПГА - 40 мм рт. ст.; пульсація біля I пальця ступні - не визначається; КПІ 0,34. Ліва гомілка: ЗГА - 30 мм рт. ст.; ПГА - 25 мм рт. ст.; пульсація біля I пальця ступні - не визначається; КПІ - 0,27. Артеріальний тиск плеча $110 / 70$ мм рт. ст. 3 метою проведення регіонарної інфузійної терапії 3.11.2008 р. хворому поставлено внутрішньоартеріально катетер у нижню епігастральну артерію зліва, через який пацієнту вводили препарат “Іломедин” (1 раз на день № 5), спазмолітики, антибіотики. На 8-му добу внутрішньоартеріальний катетер було забрано в зв'язку з його тромбозом. Враховуючи клініку та перебіг захворювання, стадію, вік пацієнта, спровоковане виник- 
нення рани у ділянці I пальця лівої ступні, а також дані функціональних та рентгенангіографічних досліджень - вирішено повторно застосувати метод непрямої реваскуляризації, а саме операцію АтАКМ у гомілки та ступні НК хворого. 13.11.2008 р. виконано операцію: АтАКМ у тканини-м'язи лівої гомілки - 180,0 мл; у праву гомілку - 140,0 мл; в обидві стопи по 20,0 мл. АКМ отримано 3 крила клубової кістки. Одночасно було виконано механічну санацію рани в ділянці кукси I пальця лівої ступні та закриття дефекту тканин штучним покриттям Suspur-derm. У найближчий післяопераційний період (3-5 доба) у хворого відмічено поліпшення: виражений больовий синдром купіруваний, потеплішала шкіра лівої ступні, став менш вираженим ціаноз шкіри тилу ступні у ділянці I пальця, нормалізувався сон. Після чіткого очищення рани, регресу запальних процесів на ступні 27.11.2008 р. виконано: висічення нежиттєздатних тканин по периферії рани, резекцію головки I плеснової кістки та закриття ранового дефекту своїми тканинами та частково штучним покриттям Suspur-derm.

9.12.2008 р. в умовах перев'язочного кабінету з метою посилення регенеративно-репаративних процесів та скорішого виникнення грануляцій під штучне покриття була виконана трансплантація алогенних фібробластів у кількості 1,5 млн. 12.12.2008 та 15.12.2008 р. було аналогічно виконано повторні трансплантації фібробластів під штучне покриття у кількості по 3,0 млн. Після появи чітких гранулятивних тканин під штучним покриттям 18.12.2008 р. виконано операцію: аутодермопластику гранулюючої рани у ділянці кукси I пальця повношаровим стоншеним шкірним клаптем, взятим в ділянці плеча. У найближчий післяопераційний період динаміка позитивна: біль не турбує, шкірний трансплантат у задовільному стані. Через 2 тижні знято шви, відмічено повне загоєння шкірного трансплантата. У задовільному стані хворого виписано на амбулаторне лікування за місцем проживання. Дані дослідження сегментарного тиску на нижніх кіниівках (31.12.2008 р.). Права гомілка: ЗГА - 45 мм рт. ст.; ПГА - 40 мм рт. ст.; пульсація біля I пальця ступні - не визначається; КПІ - 0,4. Ліва гомілка: ЗГА - 50 мм рт. ст.; ПГА - 40 мм рт. ст.; пульсація біля I пальця ступні - не визначається; КПІ 0,45 . Артеріальний тиск плеча - 110/70 мм рт. ст. У червні 2009 р. пацієнт у планову порядку був проконсультований. Відмічає позитивну динаміку: може спокійно пройти до 3 км дистанції безболісно, піднятися на 5-й поверх. При об'єктивному дослідженні шкіра на обох НК звичайного кольору, тепла при пальпації, чутливість та активні рухи нижніх кінцівок збережені. Рани та трофічна виразка правої та лівої ступні загоїлися. Пульсація збережена на підколінних артеріях обох нижніх кінцівок, пульсація артерій на ступнях не визначається. Дані дослідження сегментарного тиску на нижніх кінцівках (25.06.2009 р.). Права гомілка: ЗГА - 65 мм рт. ст.; ПГА - 50 мм рт. ст.; пульсація біля I пальця ступні - не визначається; КПІ 0,59. Ліва гомілка: ЗГА - 55 мм рт. ст.; ПГА 50 мм рт. ст.; пульсація біля I пальця ступні - не визначається; КПІ - 0,5. Артеріальний тиск плеча $-110 / 70$ мм рт. ст.

У липні 2011 р. пацієнт повторно проконсультований у НІХТ. Відмічає стабільність досягнутого раніше позитивного ефекту та поліпшення якості життя. Дані дослідження сегментарного тиску на нижніх кінцівках (02.07.2011р.). Права гомілка: ЗГА - 80 мм рт. ст.; ПГА - 70 мм рт. ст.; пульсація біля І пальця ступні - не визначається; КПІ 0,72. Ліва гомілка: ЗГА - 75 мм рт. ст.; ПГА 70 мм рт. ст.; пульсація біля I пальця ступні - не визначається; КПІ - 0,68. Артеріальний тиск плеча $-110 / 60$ мм рт. ст.

Клінічне спостереження

Хвора Т. 12 віком років госпіталізована у відділ мікросудинної та пластичної хірургії 23.02.2009 року зі скаргами на біль у литкових м'язах та стопі лівої ноги, що виникає при ходьбі на відстань до 150 м. При об'єктивному обстеженні шкіра на обох ногах звичайного кольору, тепла при пальпації, дещо холодніша на лівій стопі. Рухи в суглобах обох ніг, активні та пасивні, збережені, задовільні. Пульсація зліва спостерігається лише на стегновій артерії, дистальніше при пальпації не визначається; справа пульсація збережена, задовільна на всіх артеріях. Вважає себе хворою з 2006 року, коли після фізичного навантаження виник біль у лівій нижній кінцівці, непостійного характеру, в основному під час занять фізичними вправами (пацієнтка займалась спортивними танцями). Хвора госпіталізована в клініку, виконана рентгенангіографія судин НК. Спроба рентгенендоваскулярної дилятації сегментарної оклюзії підколінної артерії зліва не вдалася. За останні 2 роки отримала курси консервативної терапії, включаючи інфузії простагландину Е1 (Вазопростан), однак ефект був незначний. Останнім часом відмічає погіршення стану, зокрема збільшення інтенсивності болю у лівій нижній кінцівці при фізичних навантаженнях. Хворій було виконано інструментальне обстеження: визначення сегментарного тиску на НК від 23.03.2009 року. Права гомілка: ЗГА - 90 мм рт. ст.; ПГА - 105 мм рт. ст.; пульсація біля I пальця ступні - не визначається; КПІ - 
1,05. Ліва гомілка: ЗГА - 40 мм рт. ст.; ПГА - не визначається; пульсація біля I пальця стопи - не визначається; КПІ - 0,4. Артеріальний тиск плеча $-100 / 60$ мм рт. ст.

За даними лазерної доплерівської флоуметрії (ЛДФ) (24.03.2009), у хворої змішаний тип, спастичний з елементами застійно-стазичного гемодинамічного типу мікроциркуляції. У хворої відмічається помірне зниження резерву капілярного кровотоку (РККо - 144,83 \%), реактивність капілярів знижена, за даними нітрогліцеринової проби, у хворої нормальний резерв капілярного кровотоку (РККн - 370,28 \%), реактивність капілярів збережена. Рівень мікроциркуляції в судинах на правій стопі виражено знижений (ПМ - 4,76 пф. од.) за рахунок порушення притоку та спазму прекапілярних сфінктерів. За даними вейвлет-аналізу, ознаки збільшення тонусу капілярів, відмічається збільшене артеріовенулярне шунтування. Мають місце ознаки ендотеліальної дисфункції на тлі облітеруючого ендартеріїту з ураженням судин лівої нижньої кінцівки.

Ангіографія судин нижніх кінцівок: зліва має місце оклюзія підколінної артерії від щілини колінного суглоба, оклюзія ПГА, контрастуються сегменти ЗГА та малогомілкової артерії. На стопі контрастується колатеральне судинне русло.

Хворій встановлено діагноз: облітеруючий ендартеріїт артерій нижніх кінцівок, оклюзія стегново-підколінного та гомілкових сегментів зліва. ХАН II Б ст.

Враховуючи стан нижньої кінцівки та вік хворої (12 років), неефективність консервативного та ендоваскулярного лікування, сумнівні анатомічні умови для виконання реконструктивних операцій на судинах, вирішено застосувати метод непрямої реваскуляризації, який включає трансплантацію МСК ЖТ хворої у тканини-м'язи НК. 30.03.2009 хворій виконано експлантацію аспірату жирової тканини (ЖТ) з передньої черевної стінки у кількості до 100 мл для виділення та культивації МСК ЖТ. 01.04.2009 отримано суспензію ізольованих адгезивних клітин із ВСФ ЖТ в об'ємі 3 мл, де ядерних клітин - 14 млн/мл, життездатність клітин - $93 \%$. Хворій 01.04.2009 виконано введення клітин у тканини-м'язи лівої гомілки та стопи через 3 хірургічні доступи згідно з методикою, розробленою в клініці. Рани після операції на лівій нижній кінцівці загоїлися первинним натягом. У післяопераційному періоді хвора отримувала знеболювальну та антибактеріальну терапію. Стан хворої в ранньому післяопераційному періоді дещо покращився. Хвора 06.04.2009 року виписана на амбулаторне лікування. 27.04.2009 року хвора госпіталізована у відділен- ня мікросудинної та пластичної хірургії для продовження лікування. Клінічно стан хворої майже не змінився, проте дистанція безбольової ходьби збільшилась до 200 м. Хворій виконано 28.04.2009 визначення сегментарного тиску на НК. Права гомілка: ЗГА - 95 мм рт. ст.; ПГА - 105 мм рт. ст.; пульсація біля I пальця ступні - (+); КПІ - 1, 1. Ліва гомілка: ЗГА - 45 мм рт. ст.; ПГА - не визначається; пульсація біля I пальця стопи - не визначається; КПІ - 0,46. Артеріальний тиск плеча 95/60 мм рт. ст. Проведена ЛДФ (28.04.2009 р.): відмічається нормоциркуляторний з елементами спастичного гемодинамічний тип мікроциркуляції. За даними оклюзійної проби у хворої має місце помірне зменшення резерву капілярного кровотоку (РККо 207,67 \%), реактивність капілярів у нормі. За даними нітрогліцеринової проби, у хворої має місце нормальний резерв капілярного кровотоку (РККн 378,59 \%). Рівень мікроциркуляції в периферійних мікросудинах шкіри на правій стопі в межах норми (ПМ - 12,14 пф. од.). Рівень мікроциркуляції в периферійних судинах на шкірі лівої стопи незначно знижений (ПМ - 7,79 пф. од.) за рахунок незначного спазму прекапілярних сфінктерів. За даними вейвлет-аналізу, мають місце ознаки підвищеного міотонусу мікросудин. При порівнянні з ЛДФ даними від 24.03.2009 року відмічається позитивна динаміка. 29.04.2009 року хворій виконано трансплантацію аутологічних культивованих МСК ЖТ у гомілку та стопу лівої НК. У клітинній культурі - 10 млн клітин в 2 мл препарату, життєздатність - $98 \%$. У післяопераційному періоді хвора отримувала знеболювальну, протизапальну та антибіотикотерапію.

У віддаленому післяопераційному періоді хворій було виконано визначення сегментарного тиску (11.09.2009 р.). Права гомілка: ЗГА - 110 мм рт. ст.;

ПГА - 115 мм рт. ст.; пульсація біля I пальця ступні - (+); КПІ - 1,04. Ліва гомілка: ЗГА 50 мм рт. ст.; ПГА - не визначається; пульсація біля I пальця ступні - не визначається; КПІ - 0,43. Артеріальний тиск плеча - 110/60 мм рт. ст. Проведена ЛДФ (30.09.2009р.): за даними оклюзійної проби визначається помірне збільшення резерву капілярного кровотоку (РККо - 344,96 \%), реактивність капілярів в нормі. Рівень мікроциркуляції у периферійних судинах шкіри лівої стопи залишається на попередньому рівні (ПМ- 7,6 пф. од.), відмічається нормальне артеріовенулярне шунтування. Рівень мікроциркуляції у периферійних мікросудинах правої НК у межах норми. Загальний стан хворої покращився, суттєво збільшилась дистанція безбольової ходьби до 500 метрів і більше.

У червні 2012 р. пацієнтку було проконсультовано в НIXТ. Виконано визначення сегментарного 
тиску (20.06.2012 р.). Права гомілка: ЗГА 110 мм рт. ст.; ПГА - 115 мм рт. ст.; пульсація біля І пальця ступні - (+); КПІ - 1,04. Ліва гомілка: ЗГА 70 мм рт. ст.; ПГА - не визначається; пульсація біля I пальця ступні - (+); КПІ - 0,63. Артеріальний тиск плеча - 110/60 мм рт. ст. Проведена ЛДФ (20.06.2012 р.): за даними оклюзійної проби визначається помірне збільшення резерву капілярного кровотоку (РККо - 364,6 \%), реактивність капілярів у нормі. Рівень мікроциркуляції в периферійних судинах шкіри лівої стопи збільшився (ПМ 9,6 пф. од.), відмічається нормальне артеріовенулярне шунтування. Рівень мікроциркуляції в периферійних мікросудинах правої НК в межах норми. Відмічає стабільний задовільний загальний стан та чітке поліпшення якості життя (пацієнтка відновила заняття спортивними танцями).

У грудні 2012 року при телефонному анкетуванні пацієнтка відмічає стабільний задовільний стан та продовжує відвідувати заняття танцями.

Результати досліджень та їх обговорення. Оцінюючи методи оперативного лікування та одержані результати у даних хворих, треба зазначити, що патологія уражень артеріального русла нижніх кінцівок у дітей та її клінічний перебіг не є подібними, як у дорослих. Застосування реконструктивних операцій на судинах у зв'язку з сумнівними анатомічними умовами неможливе, ендоваскуляр-

\section{СПИСОК ЛІТЕРАТУРИ}

1. Пиптюк О. В. Обгрунтування і застосування автотрансплантації кісткового мозку при лікуванні хронічної ішемії нижньої кінцівки / О. В. Пиптюк, С. М. Генник // Клін. хірургія. 2003. - № 12. - C. 23-25.

2. Tabata H. Arterial gene transfer of acidic fibroblast growth factor for therapeutic angiogenesis in vivo / H. Tabata, M. Silver, J. Isner // Cardiovasc. Res. - 1997. - Vol. 35. - P. 470 - 479.

3 . Therapeutic angiogenesis by autologous bone-marrow transplantation in a general hospital setting / A. Taguchi, M. Ohtani, не лікування неефективне, а консервативне лікування (навіть 3 використанням препаратів простагландину E1 (Вазопростан), простацикліну (Іломедин), не завжди допомагає одержати очікуваний позитивний ефект. Інші оперативні технології операцій непрямої реваскуляризації, зокрема поперекова симпатектомія, ротаційні остеотрепанації великогомілкової кістки, пересадка великого сальника, які часто застосовуються у дорослих пацієнтів, не можуть бути використані у дітей. Виникла необхідність застосувати нестандартні методи оперативних технологій, які передусім спрямовані на стимуляцію процесів ангіогенезу та розвиток колатеральних судин в ішемічних тканинах, зокрема методів, що стосуються клітинних технологій.

Результати лікування та дані функціональних досліджень на прикладі клінічних спостережень доводять обгрунтованість даних методик. У хворого з IV стадією захворювання вдалося зберегти опорну функцію обох нижніх кінцівок та досягти стійкої ремісії у віддаленому періоді.

Виснов ки. 1. Трансплантація мультипотентних стромальних клітин кісткового мозку та жирової тканини є ефективним методом лікування облітеруючих захворювань артерій кінцівок у дітей.

2. У хворих із критичною ішемією альтернативи даному методу за ефективністю сьогодні нам не відомі.

T. Soma [et al.] // Eur. J. Vasc. Endovasc. Surg. - 2003. - Vol. 25. P. $276-278$.

4. Yia-Hertulla S. Cardiovascular gene therapy / S. YiaHertulla, J. Martin // Lancet. - 2000. - Vol. 355. - P. 213 222.

5. Therapeutic angiogenesis of critical lower limb ischemia. Review of the literature and prospects of research on stem cells / R. Di Stefano, U. Limbruno, D. Barone, A. Balbarini // Ital. Heart. J. Suppl. - 2004. - № 5. - P. 1-13. 